Titulo do Trabalho

\title{
A PAISAGEM GEOMORFOLÓGICA DOS CALDEIRÕES EM LAJEDO-PE SOB UMA VISÃO SISTÊMICA DO AMBIENTE
}

\author{
Nome do Autor (a) Principal
}

Jeovanes Lisboa da Silva Filho

Nome (s) do Coautor (a) (s)

Maria Betânia Moreira Amador

Nome (s) do Orientador (a) (s)

Prof ${ }^{a}$ Drª Maria Betânia Moreira Amador

Instituição ou Empresa

Universidade de Pernambuco - Campus Garanhuns

Instituição (s) de Fomento

Conselho Nacional de Desenvolvimento Cientifico e Tecnológico-CNPq

E-mail de contato

jeovanelisboa@hotmail.com

betaniaamador@yahoo.com.br

Palavras-chave

Visão Sistêmica, Paisagem e Interdisciplinaridade.

\section{INTRODUÇÃO}

Tendo-se em vista algumas paisagens geomorfológicas distribuídas na região agreste de Pernambuco, as quais se sobressaem por suas belezas que podem estimular o turismo e, em consequência, estimular o desenvolvimento local acreditase ser importante que se tenha estudos voltados para essas paisagens devido, 
principalmente devido à escassez de trabalhos voltados para as mesmas. Diante do exposto, pode-se destacar que no município de Lajedo-PE tem uma área bastante significativa que merece um olhar sistêmico ambiental para que se possa compreender a sua complexidade. Trata-se dos Caldeirões, uma formação geológicogeomorfológica que apresenta alguns tanques naturais de água que são abastecidos, principalmente, pelas águas da chuva.Essa formação geológico-geomorfológica data do período Pré-Cambriano e, devido a estrutura convexa de suas rochas afloradas, proporciona o acúmulo de águas de chuvas, também proveniente do Riacho Doce que corta toda a área urbana do município. A presença de água retida nas rochas de forma convexa foi o elemento primeiro, em grau de importância, para o surgimento dos primeiros povoamentos onde hoje se encontra o município de Lajedo. O nome do município tem sua origem, então, nesse lajedos, uma vez que esses reservatórios naturais de água potável atraiu a população para essa região.

A área dos caldeirões de Lajedo é catalogada pelo Plano de Preservação dos Sítios Históricos do Interior (PPSHI) e o Plano Diretor de Lajedo a classifica como área de proteção ambiental (APA), com lei especifica para assegurar sua preservação e conservação (DIAS, 2013, p.74)

No entanto, em tempo presente observa-se que os Caldeirões não são devidamente preservados tendo em vista vários fatores, entre os quais se pode citar a proliferação de esgotos que desaguam no Riacho Doce, bem como a ampliação tanto de bairros urbanos residenciais, quanto de favelas no entorno dessa formação, contribuindo em grande escala para o acúmulo de dejetos e lixo dos mais diversos tipos na área dos Caldeirões, o que impacta sobremaneira a paisagem em apreço. Refletindo-se sobre o termo paisagem cabe considerar que:

[...] as paisagens acumulam a história de processos tectônicos, geomorfológicos, climáticos, hidrológicos, biogeográficos e culturais, mas são, antes de tudo, entidades da ordem do presente, pois constituem o resultado geoecológico e visível da interação de elementos e processos naturais e culturais (CAVALCANTI, 2014, p.19).

\section{OBJETIVO GERAL}


- Analisar a paisagem geomorfológica dos Caldeirões em Lajedo - PE, sob uma perspectiva sistêmica.

\section{OBJETIVOS ESPECÍFICOS}

- Identificar a área onde se encontra os Caldeirões no município;

- Situar os Caldeirões no contexto ambiental do município;

- Perceber como os habitantes de Lajedo se relacionam com os Caldeirões.

\section{METODOLOGIA}

Em termos metodológicos foi de fundamental importância procurar referencial teórico que atendesse ao tema em pauta para poder falar do assunto com propriedade. Ao mesmo tempo, também se realizou visitas ao lugar fotografando e identificando, assim, elementos da paisagem atual que possam, depois, subsidiar a analise comparativa com outras fotografias que se possa encontrar em acervos dos antigos moradores. Em associação a esse trabalho busca-se dialogar com a população de forma natural, não se constitui em entrevista, embora tenha-se o eixo norteador do dialogo que e a tentativa de se perceber como a população do entorno dos Caldeirões e, também os habitantes do município percebem essa formação geológica-geomorfológica. Como referencial teórico metodológico está-se utilizando o sistemismo, o qual possibilita analisar a complexidade existente na área, bem como fazer inter-relações, uma vez que esse trabalho tem caráter interdisciplinar. Assim, compreendendo-se a potencialidade dessa paisagem e o seu significado para 0 município apresenta-se esse trabalho de iniciação cientifica, embora ainda em fase de realização. Salienta-se que o mesmo faz parte do projeto da orientadora intitulado "Contribuição ao Estudo das Paisagens Geomorfológicas do Agreste Meridional de Pernambuco sob a Visão Sistêmica do Ambiente". 


\section{RESULTADO (S)}

Os resultados ainda estão sendo obtidos mas, como considerações preliminares pode-se ressaltar impactos de ordem física, principalmente, por deposição inadequada de lixo os mais diversos e, por consequência, a poluição dos Caldeirões. Outro indicativo da falta de percepção da população, em geral, em relação importância dos Caldeirões diz respeito a vários tipos de incoerências urbanas como construção de casas e estabelecimentos comerciais, aparentemente sem respeito a esse patrimônio municipal, já estabelecido. Acredita-se, também, não haver esforço educativo em relação a eles por parte dos munícipes.

\section{CONSIDERAÇÕES FINAIS}

Nesse sentido, vale destacar a ideia do estudo da paisagem geomorfológica a partir do conceito de lugar através da uma visão sistêmica da paisagem. Dessa forma, pretende-se proporcionar algum entendimento que possa no futuro contribuir com ações eficazes para a valorização histórico-geográfica, turística e cultural dos "Caldeirões".

\section{REFERÊNCIAS}

AMADOR, Maria Betânia Moreira. Sistemismo e sustentabilidade: questão interdisciplinar. São Paulo: Scortecci, 2011.

CAVALCANTI, Lucas Costa de Souza. Cartografia de paisagens: fundamentos. São Paulo: Oficina de Textos, 2014.

DIAS, Paulo Henrique. Lajedo: uma história de lutas, conquistas e glórias. Recife: Ed. do Autor, 2013.

FLORENZANO, Teresa Gallotti (Org.). Geomorfologia: conceitos e tecnologias atuais. São Paulo: Oficina de Textos, 2008.

GUERRA, Antônio José Teixeira; CUNHA, Sandra Baptista da (Orgs.). Geomorfologia: uma atualização de bases e conceitos. 7 ed. Rio de Janeiro: Bertrand Brasil, 2007.

(Orgs.). A questão ambiental: diferentes abordagens. Rio de Janeiro: Bertrand Brasil, 2003.

JATOBÁ, Lucivânio; LINS, Rachel Caldas. Introdução a geomorfologia. 4 ed. Recife: Bagaço, 2003. 
SUERTEGARAY, Dirce Maria Antunes (Org.). Terra: feições ilustradas. 2 ed. Porto Alegre: Editora da UFRGS, 2008.

TUAN, Yi-Fu. Topofilia: um estudo da percepção, atitudes e valores do meio ambiente. Tradução: DIFEL / Difusão Editorial S. A. São Paulo: DIFEL, 1980. 